\title{
PENGARUH RASIO KEUANGAN DAN PERTUMBUHAN PENDAPATAN TERHADAP RETURN SAHAM PADA PERUSAHAAN PERKEBUNAN DI BURSA EFEK INDONESIA 2010-2017
}

\author{
Ifa Nurmasari ${ }^{1)}$ \\ 1) dosen universitas pamulang, email : dosen01550@unpam.ac.id
}

\section{ARTICLES}

INFORMATION

ABSTRACT

\section{JURNAL SEKURITAS}

(Saham, Ekonomi, Keuangan dan Investasi )

Vol.2, No.1, September 2018

Halaman : $20-31$

C LPPM \& Prodi Manajemen

UNVERSITAS PAMULANG

ISSN (online) : 2581-2777

ISSN (print) : :2581-2696

\section{Keyword:}

$\mathrm{CR}, \mathrm{ROE}, \mathrm{DER}$, return saham, and Pertumbuhan Pendapatan.

JEL. classification :

C33, G20, G23, N65

\section{Contact Author :}

PRODI MANAJEMEN UNPAM

JL.Surya Kencana No.1 Pamulang

Tangerang Selatan - Banten

Telp. (021) 7412566, Fax (021) 7412491 Email :

jurnalfinance.unpam@gmail.com
Tujuan dari penelitian ini adalah untuk mengetahui apakah terdapat pengaruh yang signifikan antara rasio keuangan (Current Ratio, Return on Equity dan Debt to Equity Ratio) dan pertumbuhan pendapatan terhadap return saham, baik secara parsial maupun simultan. Return saham merupakan tingkat keuntungan yang akan diperoleh investor. Penelitian ini menggunakan teknik purposing sampling, dimana sampel yang diambil adalah data perusahaan yang sudah terdaftar di BEI sejak 1 Januari 2010 dan perusahaan tersebut mencantumkan laporan keuangannya secara lengkap. Data dalam penelitian ini adalah data panel, yaitu terdiri dari data cross section (7 perusahaan perkebunan) dan data time series (8 tahun). Data akan diolah dengan menggunakan eview versi 10. Pada penelitian ini dilakukan berbagai uji, yaitu : uji estimasi model regresi linier, uji asumsi klasik dan uji hipotesis. Hasil penelitian menunjukkan bahwa secara parsial, CR, ROE dan pertumbuhan pendapatan tidak berpengaruh signifikan terhadap return saham. Sedangkan DER berpengaruh negatif signifikan terhadap return saham. Rasio keuangan (CR, ROE, DER) dan pertumbuhan pendapatan secara simultan berpengaruh signifikan terhadap return saham, sebesar $29 \%$.

The purpose of this study is to determine whether there is a significant influence between financial ratios (Current Ratio, Return on Equity and Debt to Equity Ratio) and revenue growth on return stock, both partially and simultaneously. Return stock is the level of profit that investors will be achieved. This study uses purposing sampling technique which the taken sample is data of companies that have been listed on the IDX since January 1, 2010 and the company has included its financial statements completely. The data in this study are panel data, which consists of cross section data (7 plantation companies) and time series (8 years) data. The data will be processed using eview version 10. In this study various tests were carried out, namely: estimation of linear regression models, classical assumption tests and hypothesis testing. The results showed that partially, CR, ROE and revenue growth had no significant effect on return stock. Moreover, DER has a significant negative effect on return stock. Financial Ratio (CR, ROE, DER) and revenue growth have significant effect on return stock simultaneously of $29 \%$. 


\section{A. Pendahuluan}

Indonesia merupakan Negara yang luas dan subur. Indonesia juga merupakan salah satu Negara terbesar di dunia dalam memproduksi kelapa sawit. Untuk bisa mempertahankan bahkan meningkatkan produksi kelapa sawit tersebut, diperlukan pengembangan teknologi dan peremajaan kelapa sawit. Hal ini tentu saja membutuhkan biaya yang sangat banyak.

Bagi perusahaan yang bergerak di bidang perkebunan,biaya atau modal dapat diperoleh dari para investor. Para investor dapat menanamkan modalnya dengan cara membeli saham perusahaan perkebunan tersebut. Dengan membeli saham, investor akan memperoleh keuntungan berupa return saham. Ada dua macam return saham yang akan diperoleh investor yaitu deviden dan capital gain. Deviden adalah sejumlah persentase tertentu dari keuntungan bersih yang dibagikan perusahaan kepada para pemilik modal. Sedangkan capital gain adalah keuntungan yang diperoleh investor yang berasal dari selisih antara harga jual saham dengan harga beli.

Untuk berinvestasi saham pada perusahaan perkebunan, investor sebaiknya mempelajari kinerja keuangan perusahaan perkebunan tersebut. Kinerja keuangan suatu perusahaan bisa dilihat dari bagaimana return sahamnya. Pada tabel dibawah, menunjukkan nilai return saham pada perusahaan perkebunan yang ada di Indonesia.

\section{Tabel Return Saham}

\begin{tabular}{|c|c|c|c|c|c|c|c|}
\hline \multirow[b]{2}{*}{ Tahun } & \multicolumn{7}{|c|}{ Perusahaan } \\
\hline & $\begin{array}{l}\text { AALI } \\
(\%)\end{array}$ & $\begin{array}{c}\text { BWPT } \\
(\%)\end{array}$ & $\begin{array}{c}\text { GZCO } \\
(\%)\end{array}$ & $\begin{array}{l}\text { LSIP } \\
(\%)\end{array}$ & $\begin{array}{c}\text { SMAR } \\
(\%)\end{array}$ & $\begin{array}{c}\text { TBLA } \\
(\%)\end{array}$ & $\begin{array}{c}\text { UNSP } \\
(\%)\end{array}$ \\
\hline 2010 & 15 & 148 & 87 & 54 & 96 & 21 & -33 \\
\hline 2011 & -17 & -13 & -38 & -13 & 28 & 44 & -27 \\
\hline 2012 & -9 & 8 & -25 & 2 & 2 & 2 & -67 \\
\hline 2013 & 27 & 3 & -45 & -16 & 2 & -4 & -46 \\
\hline 2014 & -3 & -7 & 23 & -2 & 3 & 61 & 0 \\
\hline 2015 & -35 & -7 & -3 & -3 & -48 & -32 & 0 \\
\hline 2016 & 6 & 99 & -21 & 32 & 4 & 94 & 6 \\
\hline 2017 & -22 & -33 & -17 & -18 & -21 & 29 & 226 \\
\hline
\end{tabular}

Sumber :Data diolah dari laporan keuangan (2018)

Nilai return saham pada tabel di atas, menunjukkan bahwa pada semua perusahaan perkebunan nilainya masih belum konstan. Nilai return saham positif, menunjukkan terjadi kenaikan harga saham dibandingkan dengan tahun sebelumnya. Sedangkan nilai saham negatif menunjukkan terjadi penurunan harga saham dibandingkan dengan tahun sebelumnya.

Nilai return saham dipengaruhi oleh tingkat kepercayaan investor terhadap kinerja keuangan perusahaan. Perusahaan yang mempunyai kinerja keuangan yang baik, akan mengundang semakin banyak investor untuk berinvestasi pada perusahaan tersebut. Dampaknya, harga saham perusahaan perkebunan tersebut akan naik, yang disebabkan oleh permintaan yang meningkat pada saham tersebut. Jika harga saham naik, maka return saham juga akan naik.

Nilai rasio keuangan merupakan salah satu indikator cara untuk melihat tingkat kinerja keuangan perusahaan. James C Van Horne dalam Kasmir (2015:107), membagi rasio keuangan menjadi 4 macam, yaitu likuidity ratio, leverage ratio, rasio aktivitas dan 
profitabilitas rasio. Pada masing-masing rasio tersebut, masih dibagi lagi menjadi beberapa rasio.

Current ratio adalah bagian dari Liquidity Ratio. "Menurut Kasmir (2015:134), Current Ratio menunjukkan kemampuan perusahaan dalam membayar utang jangka pendek". Nilai yang tinggi pada current ratio, menunjukkan perusahaan dalam kondisi baik, karena perusahaan mempunyai aktiva lancar dalam jumlah besar untuk membayar kewajiban jangka pendeknya.

"Return on Equity adalah kemampuan perusahaan dalam menghasilkan keuntungan dengan menggunakan modal sendiri (Sutrisno:229)". Rasio ini termasuk dalam rasio profitabilitas. Nilai Return on Equity yang tinggi menunjukkan kondisi perusahaan dalam keadaan baik, karena perusahaan mampu menghasilkan laba yang tinggi dengan menggunakan modal sendiri.

Salah satu bagian dari Leverage ratio adalah Debt to Equity Ratio."Debt to Equity Ratio (DER) adalah rasio yang digunakan untuk menilai utang dengan ekuitas (Kasmir:157)". Nilai Debt to Equity Ratio yang tinggi menunjukkan jika modal sendiri semakin sedikit dibanding dengan hutangnya.

Selain rasio keuangan, pertumbuhan pendapatan juga menunjukkan bagaimana kinerja perusahaan tersebut. Pertumbuhan pendapatan mencerminkan keberhasilan investasi periode masa lalu dari suatu perusahaan. Pertumbuhan pendapatan juga dapat digunakan untuk meramalkan bagaimana pertumbuhan perusahaan pada masa yang akan datang.

Rasio keuangan dan pertumbuhan pendapatan dapat menunjukkan bagaimana kinerja suatu perusahaan. Dari penjabaran di atas, penulis akan melakukan penelitian tentang "Pengaruh Rasio Keuangan dan Pertumbuhan Pendapatan Terhadap Return Saham Pada Perusahaan Perkebunan di Bursa Efek Indonesia tahun 2010-2017". Rasio keuangan yang akan digunakan dalam penelitian ini adalah Current Ratio (CR), Return on Equity (ROE), dan Debt to Equity Ratio (DER).

\section{B. Perumusan Masalah}

Perumusan masalah pada penelitian ini adalah :

1. Bagaimana pengaruh $\mathrm{CR}$ secara parsial terhadap return saham ?

2. Bagaimana pengaruh ROE secara parsial terhadap return saham ?

3. Bagaimana pengaruh DER secara parsial terhadap return saham ?

4. Bagaimana pengaruh pertumbuhan pendapatan secara parsial terhadap return saham?

5. Bagaimana pengaruh rasio keuangan ( $C R, R O E, D E R)$ dan pertumbuhan pendapatan secara simultan terhadap return saham?

\section{Landasan Teori}

\section{Rasio Keuangan}

"Rasio keuangan (financial ratio) merupakan kegiatan membandingkan angkaangka yang ada dalam laporan keuangan dengan cara membagi satu angka dengan angka lainnya (Kasmir, 2015:104)". Setiap rasio keuangan dapat dianalisis dengan berbagai metode, sehingga dapat lebih bermanfaat dan dapat membantu dalam pengambilan keputusan. 
Kinerja keuangan suatu perusahaan pada periode tertentu, dapat dilihat dari bagaimana nilai rasio keuangannya. Dari hasil penilaian kinerja tersebut, dapat dilakukan evaluasi mengenai hal-hal yang dapat dilakukan agar target perusahaan bisa tercapai. Bahkan dari hasil penilaian kinerja tersebut, dapat membantu pemilik perusahaan untuk mengambil keputusan, kebijakan, perencanaan perusahaan.

Laporan keuangan yang sering digunakan untuk membuat rasio keuangan adalah neraca dan laporan laba rugi. Ada lima macam rasio keuangan yang biasa digunakan, yaitu

1. Liquidity Ratio atau Solvency Ratio

Liquidity Ratio atau Solvency Ratio adalah rasio yang digunakan untuk memperlihatkan bagaimana kemampuan perusahaan dalam membayar kewajiban jangka pendek. Nilai rasio likuiditas ini didapatkan dengan membandingkan komponen yang ada di aset lancar dengan komponen yang ada di kewajiban lancar (hutang jangka pendek). Liquidity Ratio ada 3 macam yaitu Current Ratio (CR), Quick Ratio dan Cash Ratio.

2. Profitability Ratios

Profitability ratio adalah rasio yang memperlihatkan kemampuan perusahaan dalam mendapatkan keuntungan pada periode waktu tertentu. Perusahaan dikatakan mempunyai profitabilitas baik, jika dapat mencapai target keuntuntungan yang telah ditetapkan atau bahkan lebih, dengan menggunakan modal yang dimilikinya. Rasio profitability ini terdiri dari : Gross Profit Margin, Return on Equity (ROE), Net Profit Margin dan Return on Assets.

3. Efficiency Ratio atau Activity Ratio.

Efficiency ratio adalah rasio yang digunakan untuk mengukur bagaimana perusahaan dapat memanfaatkan, mengatur, mengelola sumber daya yang dimilikinya. Activity ratio terdiri dari : Recievable Turn Over (perputaran piutang), Average Collection Period (Periode Pengumpulan Pendapatan), Inventory Turnover, Total Assets Turnover dan Average Days in Inventory.

4. Leverage Ratios

Leverage ratios adalah rasio yang digunakan untuk mengukur aktiva perusahaan dibiayai oleh hutang. Rasio ini memperlihatkan besarnya hutang yang digunakan perusahaan untuk mendanai kegiatan usahanya jika dibandingkan dengan menggunakan modal sendiri. Leverage ratios terdiri dari Time Interest Earned Ratio, Debt To Total Asset Ratio, Debt To Equity Ratio (DER) dan Cash Coverage Ratio.

5. Market Value Ratios.

Market Value Ratios atau rasio pasar berhubungan dengan keuntungan yang akan diperoleh para pemilik saham. Rasio terdiri dari : Price Earning Ratio, Dividend Payout Ratio, Price Book Value Ratio, Dividend Yield dan Earning per Share.

\section{Current Ratio (CR)}

"Menurut Kasmir (2015:134), Current Ratio merupakan rasio untuk mengukur kemampuan perusahaan dalam membayar utang jangka pendek". Current Ratio adalah salah satu bagian dari Liquidity Ratio atau Solvency Ratio. Nilai current ratio yang rendah, menunjukkan bahwa perusahaan kekurangan modal untuk membayar hutang. Sebaliknya jika nilai current ratio tinggi, hal ini memperlihatkan perusahaan memiliki aktiva lancar yang tinggi yang disebabkan oleh perusahaan mendapatkan keuntungan yang tinggi. 
"Perhitungan current ratio dilakukan dengan cara membandingkan total aktiva lancar dengan total utang lancar (Kasmir, 2015: 134)". Besarnya nilai Current Ratio dapat dicari dengan menggunakan perumusan berikut:

$$
\text { Current Ratio }=\frac{\text { Aktiva Lancar }}{\text { Hutang Lancar }}
$$

\section{Return on Equity (ROE)}

Return on Equity merupakan bagian dari profitabily ratio. Return on Equity memperlihatkan bagaimana kemampuan perusahaan dalam menghasilkan laba dengan menggunakan modal sendiri. "Menurut Kasmir (2015:204), semakin tinggi rasio ROE, semakin baik. Artinya posisi pemilik perusahaan semakin kuat, demikian juga sebaliknya". Return on Equity menunjukkan bagaimana efisiensi perusahaan dalam menggunakan modal sendiri. Nilai return on equity ini, menurut Kasmir (2015:204), dapat dicari dengan menggunakan perumusan berikut :

$$
\text { Return on Equity }=\frac{E A T}{\text { Equity }}
$$

Dimana EAT adalah Earning after tax

\section{Debt to Equity Ratio (DER)}

Debt to Equity Ratio (DER) adalah rasio yang digunakan untuk menilai utang dengan ekuitas. Debt to Equity Ratio (DER) ini merupakan bagian dari Leverage ratio. "Debt to Equity Ratio ini berfungsi untuk mengetahui setiap rupiah modal sendiri yang dijadikan untuk jaminan hutang. Semakin tinggi rasio ini berarti modal sendiri semakin sedikit dibanding dengan hutangnya (Sutrisno:224)". Bagi pihak bank (kreditor), rasio ini sering digunakan untuk analisis pemberian kredit. Menurut Kasmir (2015:158), nilai DER ini bisa diperoleh dengan menggunakan perumusan berikut.

$$
\text { Debt To Equity Ratio }=\frac{\text { Total Hutang }}{\text { Equitas }}
$$

\section{Pertumbuhan Pendapatan (Growth of Revenues)}

Pertumbuhan pendapatan mencerminkan keberhasilan investasi pada periode masa lalu dari suatu perusahaan. Pertumbuhan pendapatan ini dapat meramalkan bagaimana pendapatan perusahaan pada masa yang akan datang. "Bagi perusahaan, peramalan pendapatan adalah budget yang direncanakan, sedangkan bagi analis merupakan target yang harus dicapai perusahaan pada masa yang akan datang (Manurung, 2007:48)". Jika nilai pertumbuhan pendapatan positif, menunjukkkan ada kenaikan pendapatan dibandingkan tahun sebelumnya. Jika nilainya negatif, menunjukkan adanya penurunan pendapatan dibandingkan tahun sebelumnya. Pertumbuhan pendapatan perusahaan dapat dihitung dengan rumus berikut ini :

$$
\text { Growth of revenues }=\frac{\mathrm{R} 1-\mathrm{R}(\mathrm{t}-1)}{\mathrm{R}(\mathrm{t}-1)}
$$


Dimana :

$\mathrm{R}_{1}=$ Pendapatan pada tahun ke $\mathrm{t}$.

$\mathrm{R}_{(\mathrm{t}-1)}=$ Pendapatan pada periode sebelumnya

\section{Return Saham}

"Saham adalah tanda penyertaan, andil atau pemilikan seseorang atau lembaga dalam suatu perusahaan (Hidayat, 2010:96)". Saham dibagi menjadi dua jenis, yaitu saham preferen (preferent stock) dan saham biasa (common stock). Perbedaan utama dari saham preferen dan saham biasa adalah terletak pada kewajiban dan hak yang dimiliki oleh para pemegang saham tersebut.

Salah satu keuntungan dengan memiliki saham adalah adanya return saham atau tingkat pengembalian saham. Return saham adalah laba yang akan didapatkan para pemegang saham atau investor yang telah menanamkan uangnya di pasar modal. Tingkat pengembalian atau return saham ini pada dasarnya ada dua macam yaitu :

1. Capital gain

Nilai ini diperoleh dari selisih harga saham sekarang dengan harga saham sebelumnya. Jika harga saham sekarang lebih tinggi dari harga saham sebelumnya, ini berarti terjadi capital gain atau keuntungan modal. Jika harga saham sekarang lebih rendah dari sebelumnya disebut dengan capital loss.

2. Dividen

Keuntungan yang akan diperoleh pemegang saham yang diperoleh dari laba bersih bersih perusahaan yang dibagikan kepada para pemegang saham.

Pada penelitian ini akan digunakan return saham yang nilainya berasal dari perbandingan dari selisih harga saham sekarang dikurangi harga saham sebelumnya, dibagi dengan harga saham sebelumnya. Nilai return saham ini dapat dihitung dengan menggunakan rumus :

Dimana:

$$
\mathrm{Rt}=\frac{\mathrm{Pt}-\mathrm{P}(\mathrm{t}-1)}{\mathrm{P}(\mathrm{t}-1)}
$$

$\mathrm{R}_{\mathrm{t}} \rightarrow$ Return saham pada tahun ke $t$

$\mathrm{P}_{\mathrm{t}} \rightarrow$ Harga penutupan saham pada akhir tahun ke $t$

$\mathrm{P}_{(\mathrm{t}-1)} \rightarrow$ Harga penutupan saham pada akhir tahun ke $t-1$

\section{Metodologi Penelitian}

Penelitian ini berjenis kuantitatif, yaitu berupa data-data yang akan dianalisis menggunakan eviews versi 10 . Tujuan dari penelitian ini adalah untuk mengetahui bagaimana pengaruh rasio keuangan ( $C R, R O E$ dan $D E R$ ) dan pertumbuhan pendapatan terhadap return saham pada perusahaan perkebunan di Bursa Efek Indonesia dari 2010 sampai 2017.

\section{Populasi Dan Sampel}

1 Populasi

Pada penelitian ini akan digunakan populasi semua perusahaan sub sektor perkebunan yang telah go public yang ada di Indonesia. Perusahaan sub sektor perkebunan yang telah go public ini berjumlah 16 perusahaan.

\section{Sampel}


Dalam penelitian ini akan digunakan teknik purposing sampling. Purposing sampling adalah teknik pemilihan sampel dengan menggunakan kriteria tertentu, yaitu sebagai berikut :

a) Perusahaan sub sektor perkebunan yang diteliti, telah terdaftar di Bursa Efek Indonesia dari 1 Januari 2010 sampai dengan 31 Desember 2017.

b) Perusahaan perkebunan yang dijadikan sampel mempunyai data yang lengkap.

Dari data yang didapatkan, jumlah perusahaan sub sektor perkebunan yang telah go public sebanyak 16 perusahaan. Dari 16 perusahaan tersebut, hanya 7 perusahaan yang memenuhi kriteria di atas. Pada penelitian ini menggunakan data panel, yaitu gabungan antara data cross section (7 perusahaan perkebunan) dengan data time series (data berdasarkan urutan waktu dari tahun 2010 sampai 2017).

\section{Analisis Data}

Pada penelitian ini menggunakan analisis data sebagai berikut :

\section{Estimasi Model Regresi Linier}

Pada penelitian ini menggunakan estimasi model regresi linier yang dilakukan dengan memakai software Eviews (Econometric Views) versi 10 yaitu sebagai berikut :

$$
Y_{\text {it }} \quad=\beta_{0}+\beta_{1} X_{1, i t}+\beta_{2} X_{2, i t}+\beta_{3} X_{3, i t}+\beta_{4} X_{4, i t}+\varepsilon_{i t}
$$

Model regresi linier pada data panel ada 3 macam, yaitu common effect, fixed effect dan random effect. Untuk memilih model mana yang paling sesuai dengan data yang dimiliki, maka akan dilakukan uji chow, uji housman dan uji lagrange multiplier.

\subsection{Uji Model Common Effect}

Pada analisis regresi data panel, model common effect adalah model yang paling sederhana. "Asumsi yang digunakan dalam model common effect ini adalah menganggap bahwa intersep dan slope selalu tetap baik antar waktu maupun antar individu (Sriyana, 2014:107)". Pada model common effect ini, analisis regresi data panelnya akan mengabaikan pengaruh waktu dan individu pada model yang dibentuknya.

\subsection{Uji Model Fixed Effect}

Pada model fixed effect ini menunjukkan perbedaan konstanta antar objek, meskipun dengan koefisien regresi yang sama. Efek tetap pada model ini maksudnya adalah bahwa satu objek, pada berbagai waktu akan memiliki konstanta dan koefisien regresi yang besarnya tetap.

\subsection{Uji Model Random Effect}

"Pada model random effect, terjadinya perbedaan intersep dan konstanta atau slope disebabkan oleh residual atau error sebagai akibat adanya perbedaan antar unit dan antar periode waktu yang terjadi secara random (Sriyana, 2014:153)".

\subsection{Uji Chow}

Uji chow digunakan untuk memilih mana yang lebih baik, antara model common effect dan model fixed effect. Ketentuan yang digunakan dalam mengambil keputusan :

i. Model common effect, jika nilai probability lebih besar dari 0,05

ii. Model fixed effect, jika nilai probability lebih kecil dari 0,05.

\subsection{Uji Housman}

Uji housman digunakan untuk memilih mana yang lebih baik, antara model random effect dan fixed effect. Ketentuan yang digunakan dalam mengambil keputusan :

i. Model random effect, jika nilai probability lebih besar dari 0,05

ii. Model fixed effect, jika probability lebih kecil dari 0,05. 


\subsection{Uji Lagrange Multiplier}

Uji lagrange multiplier digunakan untuk memilih mana yang lebih baik antara model random effect dan common effect. Ketentuan yang digunakan dalam mengambil keputusan :

i. Model common effect, jika nilai probability lebih basar dari 0,05

ii. Model random effect, jika nilai probability lebih kecil dari 0,05 .

\section{Uji Asumsi Klasik}

Uji asumsi klasik ini dilakukan untuk mengetahui apakah hasil regresi memiliki kriteria BLUE, yaitu Best, Linear, Unbiased, Estimator. Uji asumsi klasik yang dilakukan antara lain : uji autokorelasi, uji normalitas, uji multikolinearitas dan uji heteroskedastisitas.

\subsection{Uji Normalitas}

Tujuan melakukan uji normalitas ini adalah untuk mengetahui apakah variabel residual atau pengganggu pada model regresi, mempunyai distribusi normal atau tidak."Menurut Winarno (2015:5.41), dalam anailisis multivariate, para peneliti menggunakan pedoman kalau variabel terdiri atas 30 data, maka data sudah berdistribusi normal". Dengan menggunakan eviews versi 10, uji normalitas untuk mendeteksi apakah residualnya berdistribusi normal atau tidak, dapat dilakukan dengan dua cara, yaitu dengan uji Jarque-Bera dan histogram. Pengujian ini dilakukan dengan melihat nilai Jarque-Bera (J-B) dan probabilitasnya.

\subsection{Uji Multikolinearitas}

"Multikolinearitas adalah kondisi adanya hubungan linear antar variabel independen (Winarno, 2015:5.1)". Terjadi multikolinearitas apabila nilai korelasi antara variabel bebas lebih besar dari 0,80.

\subsection{Uji Autokorelasi}

"Menurut Winarno (2015 : 5.29), aotokorelasi adalah hubungan antara residual satu observasi dengan residual observasi lainnya". Tujuan melakukan autokorelasi ini adalah untuk melihat apakah model linier yang digunakan mempunyai korelasi antara kesalahan pengganggu. Pada Uji autokorelasi bisa dilihat dari nilai Durbin-Watson pada hasil model regresi yang digunakan.

\subsection{Uji Heterokedatisitas}

"Menurut Sarjono dan Julianita (2011:66), heterokedatisitas menunjukkan bahwa varian variabel tidak sama untuk semua pengamatan / observasi". Sedangkan dikatakan homokedastisitas, jika varian dari satu residual pengamatan ke pengamatan yang lain besarnya sama.

\section{Rancangan Hipotesis}

Uji hipotesis merupakan uji untuk mengetahui kebenaran hipotesis yang pada penelitian ini. Uji hipotesis yang akan dilakukan pada penelitian ini adalah uji t, uji $F$ dan uji koefisien determinasi.

\subsection{Uji t}

Uji t ini dilakukan untuk mengetahui apakah secara parsial variabel-variabel bebas yang digunakan mempunyai pengaruh signifikan terhadap variabel terikat. Derajat signifikasi yang digunakan pada penelitian ini adalah 0,05.

i. Jika nilai probability $<0,05$, maka $\mathrm{H}_{\mathrm{a}}$ diterima dan $\mathrm{H}_{\circ}$ ditolak. Ini artinya secara parsial variabel bebas berpengaruh signifikan terhadap variabel terikat. 
ii. Jika nilai probability $>0,05$, maka $\mathrm{H}_{\circ}$ diterima dan $\mathrm{H}_{\mathrm{a}}$ ditolak. Ini artinya secara parsial variabel bebas tidak berpengaruh signifikan terhadap variabel terikat .

Selain melihat nilai probabilitas pada model regresi, pengujian pengaruh variabel bebas terhadap variabel terikat secara parsial ini juga dilakukan dengan membandingkan antara

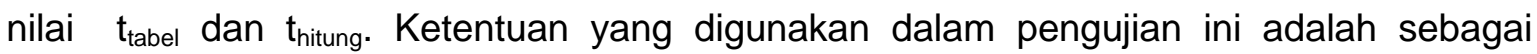
berikut:

i. Apabila $-\mathrm{t}_{\text {tabel }} \leq \mathrm{t}_{\text {hitung }} \leq+\mathrm{t}_{\text {tabel, }}$, maka $\mathrm{H}_{\mathrm{o}}$ diterima dan $\mathrm{H}_{\mathrm{a}}$ ditolak,

ii. Apabila $t_{\text {hitung }} \leq-t_{\text {tabel }}$ atau $t_{\text {hitung }}>+t_{\text {tabel, }}$ maka $\mathrm{H}_{\mathrm{a}}$ diterima dan $\mathrm{H}_{\mathrm{o}}$ ditolak.

\subsection{Uji F}

Untuk mengetahui apakah secara simultan semua variabel bebas berpengaruh signifikan terhadap variabel terikat, maka dilakukanlah uji F. Derajat signifikasi yang digunakan adalah 0,05. Dasar pengambilan keputusannya adalah sebagai berikut:

i. Jika probabilitas $F$ statistik $>0,05$ dan $\mathrm{F}_{\text {hitung }}<\mathrm{F}_{\text {tabel }}$ maka $\mathrm{H}_{0}$ diterima dan $\mathrm{H}_{\mathrm{a}}$ ditolak. Ini artinya secara simultan vaaariabel bebas tidak berpengaruh signifikan terhadap variable terikat.

ii. Jika probabilitas $\mathrm{F}$ statistik $<0,05$ dan $\mathrm{F}_{\text {hitung }}>\mathrm{F}_{\text {tabel }}$ maka $\mathrm{H}_{0}$ ditolak dan $\mathrm{H}_{\mathrm{a}}$ diterima. Ini artinya secara simultan variabel bebas berpengaruh signifikan terhadap variabel terikat.

\subsection{Koefisien Determinasi}

Koefisien determinasi $\left(R^{2}\right)$ menjelaskan seberapa besar variabel bebas dalam menjelaskan variabel terikat. Untuk melihat besarnya varibel bebas memberikan pengaruh pada veriabel terikat bisa dilihat pada nilai adjusted $\mathrm{R}$ squarenya.

\section{E. Hasil Estimasi Data dan Hasil Penelitian}

\section{Hasil Estimasi Model Regresi Data Panel}

Berbagai uji dilakukan untuk mendapatkan model yang paling sesuai untuk mengetahui bagaimana pengaruh rasio keuangan ( $C R, R O E, D E R)$ dan pertumbuhan pendapatan terhadap return saham pada perusahaan perkebunan. Uji yang dilakukan untuk estimasi model regresi linier data panel pada penelitian ini adalah uji common effect, uji fixed effect dan uji random effect. Kemudian dilanjutkan dengan uji chow, uji Housman dan uji Lagrange Multiplier, untuk memilih model mana yang paling sesuai untuk model analisis regresi linier pada penelitian ini.

Setelah dilakukan keenam pengujian tersebut didapatkan model yang paling sesuai adalah model common effect. Hasil dari uji common effect ini dapat dilihat pada tabel Model Common Effect dibawah. Setelah didapatkan model common effect, dilanjutkan dengan melakukan uji asumsi klasik, yang terdiri dari uji autokorelasi, uji normalitas, uji heteroskedastisitas dan uji multikolinearitas.

Pada tabel Model Common Effect yang digunakan pada penelitian ini, didapatkan persamaan sebagai berikut :

$$
\begin{aligned}
& Y=15.12215-0.044468 X_{1}+0.382054 X_{2}-0.074238 X_{3}+0.09370 X_{4} \\
& \mathrm{t}_{\text {hitung }}=\left(\begin{array}{lllll}
(1.490486) & (-0.670103) & (1.545507) & (-5.119479) & (0.133088
\end{array}\right) \\
& \mathrm{F}_{\text {hitung }}=6.620689
\end{aligned}
$$


Tabel Model Common Effect

Pengaruh CR, ROE, DER dan PP Terhadap RS

\begin{tabular}{|c|c|c|c|c|}
\hline $\begin{array}{l}\text { Dependent Variable: } \\
\text { Method: Panel Least } \\
\text { Date: } 08 / 10 / 18 \text { Tim } \\
\text { Sample: } 20102017 \\
\text { Periods included: } 8 \\
\text { Cross-sections incluc } \\
\text { Total panel (balancec }\end{array}$ & $\begin{array}{l}\text { : } 7 \\
\text { bservations: }\end{array}$ & & & \\
\hline Variable & Coefficient & Std. Error & t-Statistic & Prob. \\
\hline $\mathrm{C}$ & 15.12215 & 10.14578 & 1.490486 & 0.1423 \\
\hline CR & -0.044468 & 0.066360 & -0.670103 & 0.5058 \\
\hline ROE & 0.382054 & 0.247203 & 1.545507 & 0.1284 \\
\hline DER & -0.074238 & 0.014501 & -5.119479 & 0.0000 \\
\hline $\mathrm{PP}$ & 0.009370 & 0.070406 & 0.133088 & 0.8946 \\
\hline R-squared & 0.341789 & Mean deper & ent var & 6.946429 \\
\hline Adjusted R-squared & 0.290165 & S.D. depenc & nt var & 53.21019 \\
\hline S.E. of regression & 44.83050 & Akaike info & iterion & 10.52870 \\
\hline Sum squared resid & 102498.5 & Schwarz cri & rion & 10.70954 \\
\hline Log likelihood & -289.8036 & Hannan-Qu & n criter. & 10.59881 \\
\hline F-statistic & 6.620689 & Durbin-Wats & n stat & 1.889112 \\
\hline Prob(F-statistic) & 0.000227 & & & \\
\hline
\end{tabular}

Sumber : Hasil Penelitian diolah (2018)

\section{Uji Hipotesis}

\subsection{Uji t}

Uji t dilakukan untuk mengetahui apakah rasio keuangan (CR, ROE, DER) dan Pertumbuhan Pendapatan secara parsial memiliki pengaruh yang signifikan terhadap Return Saham pada perusahaan perkebunan. Uji $t$ ini dilakukan dengan menggunakan derajat siginifikasi sebesar $5 \%$.

\subsubsection{Pengaruh CR terhadap Return Saham.}

Dari pengujian regresi linier model common effect, diperoleh hasil nilai $t_{\text {-hitung }}$ Current Ratio sebesar -0,0670103. Sedangkan nilai $t_{\text {tabel }}$ pada penelitian ini adalah 2,00756. Pada pengaruh $C R$ terhadap return saham pada perusahaan perkebunan diperoleh $t_{\text {hitung }}<t_{\text {tabel }}$ yaitu $0,670103<2,00756$, dengan nilai probabilitas $0,5058>0,05$. Ini berarti, pada uji t menunjukkan bahwa $\mathrm{H}_{a}$ ditolak dan $\mathrm{H}_{0}$ diterima. Nilai tersebut memperlihatkan bahwa CR tidak berpengaruh signifikan terhadap Return Saham. Tanda negatif pada koefisien variable CR menunjukkan bahwa hubungan antara CR dan return saham adalah berlawanan arah. Semakin besar nilai CR akan memberi pengaruh nilai return saham menjadi semakin kecil.

\subsubsection{Pengaruh ROE terhadap Return Saham.}

Dari pengujian regresi linier model common effect, diperoleh hasil nilai $t_{\text {-hitung }}$ Return on Equity sebesar 1,545507. Sedangkan nilai $t_{\text {tabel }}$ pada penelitian ini adalah 2,00756. Pada pengujian pengaruh ROE terhadap return saham pada perusahaan perkebunan diperoleh $t_{\text {hitung }}<t_{\text {tabel }}$ yaitu $1,545507<2,00756$, dengan nilai probabilitas sebesar 0,1284>0,05. Ini berarti, pada uji t menunjukkan bahwa $\mathrm{H}_{\mathrm{a}}$ ditolak dan $\mathrm{H}_{0}$ diterima. Nilai tersebut memperlihatkan bahwa ROE tidak berpengaruh signifikan terhadap Return Saham. Tanda positif pada koefisien variabel ROE menunjukkan bahwa 
hubungan antara ROE dan return saham adalah searah. Semakin besar nilai ROE akan memberi pengaruh nilai return saham menjadi besar.

\subsubsection{Pengaruh DER terhadap Return Saham.}

Dari pengujian regresi linier model common effect, diperoleh hasil nilai $t_{\text {-hitung }}$ Debt to Equity Ratio $-5,119470$. Sedangkan nilai tabel pada penelitian ini adalah 2,00756. Pada pengujian pengaruh DER terhadap return saham pada perusahaan perkebunan diperoleh $t_{\text {hitung }}>t_{\text {tabel }}$ yaitu $5,119470>2,00756$, dengan nilai probabilitas sebesar $0,0000<0,05$. Ini berarti, pada uji t menunjukkan bahwa $\mathrm{H}_{0}$ ditolak dan $\mathrm{H}_{a}$ diterima. Nilai tersebut memperlihatkan bahwa DER berpengaruh signifikan terhadap Return Saham. Nilai negatif pada koefisien variabel DER menunjukkan bahwa antara DER dan return saham mempunyai hubungan yang berlawanan. Semakin besar nilai DER akan memberikan pengaruh nilai return saham menjadi kecil.

\subsubsection{Pengaruh pertumbuhan pendapatan terhadap Return Saham.}

Dari pengujian regresi linier model common effect, diperoleh hasil nilai $t_{\text {-hitung }}$ pertumbuhan pendapatan sebesar 0,133088 . Sedangkan nilai $t_{\text {tabel }}$ pada penelitian ini adalah 2,00756. Pada pengujian pengaruh pertumbuhan pendapatan terhadap return saham pada perusahaan perkebunan diperoleh $t_{\text {hitung }}<t_{\text {tabel }}$ yaitu $0,133088<2,00756$, dengan nilai probabilitas sebesar $0,8946>0,05$. Ini berarti, pada uji t menunjukkan bahwa $\mathrm{H}_{\mathrm{a}}$ ditolak dan $\mathrm{H}_{0}$ diterima. Nilai tersebut memperlihatkan bahwa pertumbuhan pendapatan tidak berpengaruh signifikan terhadap Return Saham. Nilai positif pada koefisien variabel pertumbuhan pendapatan menunjukkan bahwa hubungan antara pertumbuhan pendapatan adalah searah. Semakin besar nilai pertumbuhan pendapatan akan memberikan pengaruh nilai return saham menjadi besar.

\subsection{Uji F}

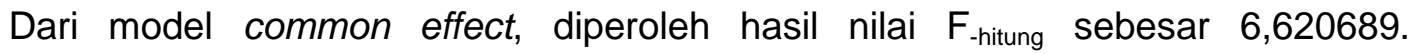
Sedangkan nilai $F_{\text {tabel }}$ pada penelitian ini adalah 2,56. Pada pengujian pengaruh rasio keuangan ( $C R, R O E, D E R)$ dan pertumbuhan pendapatan terhadap return saham pada perusahaan perkebunan diperoleh $F_{\text {hitung }}>F_{\text {tabel }}$ yaitu 6,620689 $>2,56$ dengan nilai probabilitas sebesar $0,00022728<0,05$. Ini berarti pada uji $F$, secara simultan rasio keuangan (CR, ROE, DER) dan pertumbuhan pendapatan berpengaruh signifikan terhadap return saham.

\subsection{Koefisien Determinasi $\left(\mathbf{R}^{2}\right)$}

Koefisien determinasi $\left(\mathrm{R}^{2}\right)$ memperlihatkan kemampuan variabel independen untuk menjelaskan variabel dependen. Berdasarkan hasil perhitungan dengan menggunakan model regresi common effect pada pengujian pengaruh rasio keuangan (CR, ROE, DER) dan pertumbuhan pendapatan terhadap return Saham pada perusahaan perkebunan, didapatkan nilai koefisien Adjuted $R^{2}=0,290165$ atau $29,0165 \%$. Ini artinya secara simultan rasio keuangan (CR, ROE, DER) dan pertumbuhan pendapatan memberikan pengaruh yang signifikan sebesar $29,0165 \%$ terhadap return saham. Ada variabel lain diluar penelitian ini yang mempengaruhi return saham sebesar $70,9835 \%$

\section{F. Analisis Hasil Penelitian dan Pembahasan \\ 1. Pengaruh CR Terhadap Return Saham.}


Dari pengujian regresi linear model common effect didapatkan hasil bahwa CR tidak berpengaruh signifikan terhadap Return Saham. Tanda negatif pada koefisien variabel $C R$ mempunyai arti bahwa hubungan antara $C R$ dan return saham adalah berlawanan. Semakin kecil nilai $\mathrm{CR}$, akan mengakibatkan nilai return saham akan meningkat, demikian pula sebaliknya.

Current Ratio merupakan rasio yang digunakan untuk mengukur kemampuan perusahaan untuk membayar utang yang segera harus dilunasi atau utang jangka pendek. CR menggambarkan seberapa besar aktiva lancar yang tersedia untuk menutupi hutang jangka pendek. Nilai CR yang tinggi, memperlihatkan bahwa perusahaan mempunyai aktiva lancar dalam jumlah besar. Aktiva lancar ini bisa berasal dari laba perusahaan yang tinggi. Laba yang tinggi yang diperoleh perusahaan, menunjukkan kinerja keuangan perusahaan tersebut berjalan yang baik. Sehingga akan semakin banyak investor yang tertarik untuk berinvestasi membeli saham perusahaan tersebut. Permintaan investasi (saham) yang meningkat, menyebabkan harga saham menjadi naik. Hal ini mengakibatkan return saham ikut naik.

Dari uji regresi linier model common effect, didapatkan nilai koefisien variabel $C R$ adalah negatif. Semakin besar nilai CR, justru akan mengakitkan nilai return saham menjadi turun. Jika perusahaaan mempunyai nilai $C R$ tinggi, maka perusahaan perkebunan mempunyai aktiva lancar dalam jumlah besar. Bagi sebagain investor, akan beranggapan bahwa perusahaan perkebunan tidak bisa memanfaatkan aktiva lancar tersebut untuk mengembangkan usahanya. Selain itu aktiva lancar yang tinggi juga bisa menunjukkan bahwa persentase keuntungan yang dibagikan ke pemilik perusahaan perkebunan kecil. Hal tersebut menyebabkan permintaan saham pada perusahaan perkebunan menjadi turun. Sehingga harga saham perusahaan perkebunan ikut turun dan return saham yang didapatkan investor menjadi menurun.

\section{Pengaruh Return On Equity (ROE) Terhadap Return Saham (RS).}

Hasil pengujian regresi linier model common effect untuk menguji pengaruh ROE terhadap Return Saham adalah bahwa secara parsial tidak terdapat pengaruh signifikan dari variabel ROE terhadap variabel Return Saham. Koefisien variabel ROE bernilai positif, ini artinya pengaruh ROE terhadap RS adalah tidak berlawanan. Dimana semakin besar nilai ROE, akan berpengaruh pada semakin besar pula nilai return saham.

Return on Equity merupakan rasio yang digunakan untuk mengukur laba bersih setelah pajak (EAT) dengan menggunakan modal sendiri. Semakin tinggi nilai rasio ROE, menunjukkan kondisi perusahaan perkebunan yang semakin baik. Jika nilai ROE tinggi, berarti perusahaan dengan menggunakan modalnya sendiri, mampu menghasilkan laba yang tinggi. Hal tersebut akan menarik investor untuk berinvestasi membeli saham pada perusahaan perkebunan. Jika permintaan akan saham meningkat, tentu saja akan mengakibatkan harga saham pada perusahaan perkebunan menjadi naik. Jika harga saham naik, maka para invertor akan mendapatkan return saham yang tunggi.

\section{Pengaruh Debt to Equity Ratio (DER) terhadap Return Saham (RS)}

Pada pengujian regresi linier model common effect, didapatkan hasil bahwa DER berpengaruh signifikan terhadap return saham. Koefisien variabel DER bernilai negatif, ini berarti pengaruh DER tehadap return saham adalah berlawanan arah. Jika nilai DER 
meningkat, akan berpengaruh atau mengakibatkan nilai return saham menjadi turun, demikian pula sebaliknya.

Debt to Equity Ratio merupakan rasio yang diperoleh dari perbandingan hutang yang dimiliki perusahaan dengan modalnya. Jika nilai DER tinggi, artinya hutang yang dimiliki perusahaan juga tinggi jika dibandingkan dengan jumlah modal sendiri. Nilai DER yang tinggi, menyebabkan perusahaan harus mengeluarkan beban yang tinggi untuk membayar hutang dan bunganya, sehingga laba bersih perusahaan menjadi berkurang. Jika laba bersih berkurang, maka bagian laba yang akan dibagikan perusahaan ke pemilik saham menjadi berkurang bahkan kadang tidak dibagikan sama sekali. Jika keuntungan pemilik saham menurun, maka permintaan akan saham perusahaan perkebunan tersebut juga akan turun, harga saham pun ikut turun. Akhirnya return saham juga ikut turun.

\section{Pengaruh Pertumbuhan Pendapatan terhadap Return Saham (RS).}

Hasil pengujian regresi linier model common effect, menunjukkan variabel pertumbuhan pendapatan berpengaruh tidak signifikan terhadap variabel Return Saham. Tanda positif yang ditunjukkan oleh nilai koefisien variabel pertumbuhan pendapatan mempunyai arti bahwa pertumbuhan pendapatan dan Return Saham memiliki hubungan yang searah. Semakin rendah nilai pertumbuhan pendapatan, maka nilai Return Saham juga akan rendah, demikian pula sebaliknya.

Pertumbuhan pendapatan menunjukkan adanya peningkatan atau penurunan pendapatan dibandingkan dengan tahun sebelumnya. Apabila nilai pertumbuhan pendapatan positif, maka perusahaan mengalami peningkatan pendapatan, dan menggambarkan kondisi perusahaan semakin membaik. Hal ini akan membuat investor tertarik untuk berinvestasi pada perusahaan perkebunan tersebut. Dengan adanya permintaan saham yang meningkat, harga saham menjadi naik, sehingga Return Saham yang diperoleh investor juga naik.

\section{Pengaruh Rasio Keuangan (CR, ROE, DER) dan Pertumbuhan Pendapatan Secara Simultan Terhadap Return Saham.}

Berdasarkan hasil uji regresi linier berganda pada pengujian pengaruh rasio keuangan ( $\mathrm{CR}, \mathrm{ROE}, \mathrm{DER})$ dan Pertumbuhan Pendapatan terhadap return saham dengan menggunakan model common effect diperoleh nilai $F_{\text {hitung }}>F_{\text {tabel }}(6,620689>$ 2,56 ) dengan nilai probabilitas $0,000227<0,05$. Ini berarti Rasio keuangan (CR, ROE, DER) dan pertumbuhan pendapatan secara simultan berpengaruh signifikan terhadap return saham perusahaan perkebunan. Rasio keuangan (CR, ROE, DER) dan pertumbuhan pendapatan secara simultan mempengaruhi return saham sebesar $29,0165 \%$. Ini artinya ada variabel lain diluar variabel bebas dari penelitian ini yang mempengaruhi return saham sebesar $70,9835 \%$.

\section{G. Kesimpulan dan Saran}

1. Kesimpulan

Berdasarkan penelitian "Pengaruh Rasio Keuangan dan Pertumbuhan Pendapatan Terhadap Return Saham Pada Perusahaan Perkebunan di BEI Tahun 2010 2017", yang telah dilakukan, maka menghasilkan kesimpulan antara lain : 
1. CR secara parsial tidak berpengaruh signifikan terhadap Return Saham. Hal ini ditunjukkan dengan $t_{\text {hitung }}<t_{\text {tabel }}(0,670103<2,00758)$ dengan nilai signifikansi $0,5058>0,05$.

2. ROE secara parsial tidak berpengaruh signifikan terhadap Return Saham. Hal ini ditunjukkan dengan $t_{\text {hitung }}<t_{\text {tabel }}(1,545507<2,00758)$ dengan nilai signifikansi $0,1284>0,05$.

3. DER secara parsial berpengaruh negatif signifikan terhadap Return Saham. Hal ini ditunjukkan dengan $t_{\text {hitung }}>t_{\text {tabel }}(5.119479>2,00756)$ dengan nilai signifikansi $0,0000<0,05$.

4. Pertumbuhan Pendapatan secara parsial tidak berpengaruh signifikan terhadap Return Saham. Hal ini ditunjukkan dengan $t_{\text {hitung }}<t_{\text {tabel }}(0,133088<2,00758)$ dengan nilai signifikansi 0,8945 >0,05.

5. Secara simultan Rasio keuangan (CR, ROE, DER) dan pertumbuhan pendapatan berpengaruh signifikan terhadap Return Saham. Hal ini ditunjukkan nilai $F_{\text {hitung }}>$ $F_{\text {tabel }}(6,620689>2,56)$ dengan nilai signifikansi 0,000227 $<0,05$. Sedangkan besarnya pengaruh Rasio keuangan ( $C R$, ROE, DER) dan pertumbuhan pendapatan secara simultan terhadap Return Saham dapat dilihat dari nilai Adjusted $\mathrm{R}^{2}=0,290165$. Ini artinya Rasio keuangan (CR, ROE, DER) dan pertumbuhan pendapatan berpengaruh secara simultan terhadap Return Saham sebesar $29,0165 \%$.

\section{Saran}

Setelah melakukan penelitian, dengan segala keterbatasan penulis ingin memberikan saran yang sekiranya dapat membantu berbagai pihak :

1. Sebaiknya dilakukan penelitian lagi dengan menggunakan data yang lebih banyak.

2. DER berpengaruh negatif signifikan terhadap return saham. Ini artinya jika nilai DER besar, maka nilai return saham menjadi kecil. Oleh karena itu, sebaiknya perusahaan menurunkan nilai DER ini agar nilai return saham menjadi besar, dengan cara mengurangi hutang perusahaan.

3. Secara simultan, CR, ROE, DER dan Pertumbuhan Pendapatan berpengaruh 29\% terhadap return saham. Ini artinya, sekitar $79 \%$ return saham dipengaruhi oleh variabel lain. Sebaiknya dilakukan penelitian lagi dengan menggunakan variabelvariabel lain, baik itu variabel yang berhubungan dengan mikroekonomi maupun variabel yang berhubungan dengan makroekonomi.

\section{H. Daftar Pustaka}

Atmaja, L.S., 2008, "Teori dan Praktik Manajemen Keuangan”, Penerbit Andi, Yogyakarta. Dirgantoro, C., 2002, "Keunggulan Bersaing Melalui Proses Bisnis”, Jakarta, PT Grasindo. Gujarati, 2004, "Basic Econometrics", The McGraw-Hill Companies.

Hidayat, T., 2010, "Buku Pintar Investasi”, Jakarta, Mediakita.

Horne, J. C. V. dan Wachowicz, J. M., 2007, "Fundamental of Financial Management", Jakarta, Salemba Empat.

Horne, V., James, C., John, M., dan Wachowicz, J.R., 2007, "Prinsip-prinsip Manajemen Keuangan", Jakarta, Penerbit Salemba Empat.

Kasmir, 2015, “Analisis Laporan Keuangan”, Jakarta, PT Raja Grafindo Persada. 
Manurung, A. H., 2007, “Cara Menilai Perusahaan”, Jakarta, PT Elex Media Komputindo.

Nurmasari, Ifa, 2017, “Analisis Current Ratio, Return on Equity, Debt to Equity Ratio dan Pertumbuhan Pendapatan Berpengaruh Terhadap Return Saham Pada Perusahaan Pertambangan di Bursa Efek Indonesia Tahun 2010-2014", Jurnal Kreatif : Pemasaran, Sumberdaya Manusia dan Keuangan, Vol. 5, No.1, Oktober 2017.

Rangkuti, F., 2012, "Studi Kelayakan Bisnis Dan Investasi," Jakarta, PT Gramedia Pustaka Utama.

Sriyana, J, 2014, "Metode Regresi Data Panel”, Yogyakarta, Ekonisia.

Sugiyono, 2014, "Metode Penelitian Kombinasi", Penerbit Alfabeta, Bandung.

Weston, J.F. dan Copeland, T.E., "Manajemen Keuangan Edisi Kesembilan Jilid 1", Penerbit Binarupa Aksara, Grogol.

Widarjono, A., 2007, "EkonometrikaTeori dan Aplikasi untuk Ekonomi dan Bisnis", Ekonisia, Yogyakarta.

Wild, J. J., Subramanyam, K. R. dan Halsey, R. E., 2005, "Financial Statement Analysis", Jakarta, Salemba Empat.

Winarno, W. W., 2015, "Analisis Ekonometris dan Statistika dengan EViews", Yogyakarta, UPP STIM YKPN. 